\title{
Effects of explant, media and growth regulators on in vitro regeneration and antioxidant activity of Juniperus phoenicea
}

\author{
Ezz Al-Dein Al-Ramamneh ${ }^{1}$, Nidal Daradkeh ${ }^{2}$, Taha Rababah ${ }^{3}$, Daniel Pacurar ${ }^{4}$, Maisa Al-Qudah ${ }^{5}$ \\ ${ }^{1}$ Department of Agricultural Sciences, AL-Shouback University College, Al-Balqa Applied University, Maan, \\ Jordan \\ ${ }^{2}$ Biotechnology Department, Tissue culture Laboratory, National Center for Agricultural Research and \\ Extension, Baq'a, Jordan \\ ${ }^{3}$ Department of Nutrition and Food Technology, Faculty of Agriculture, Jordan University of Science and \\ Technology, Irbid, Jordan \\ ${ }^{4}$ SweTree Technologies AB, P.O Box 4095, SE-904 03 Umeå, Sweden \\ ${ }^{5}$ Department of Medical Laboratory Sciences, Faculty of Science, Al-Balqa Applied University, Al-Salt, Jordan
}

*Corresponding author: ezznew@ hotmail.com; ezznew@bau.edu.jo

\begin{abstract}
Juniperus phoenicea is an ornamental shrub that is also used to flavor food and to supply medicines and timber. Its micropropagation is of industrial concern and can occur by axillary shoot multiplication. Microcuttings of J. phoenicia were established in vitro on Murashige and Skoog (MS) and Rugini Olive (OM) media in glass tubes (25 mm x $150 \mathrm{~mm})$. Factors studied were explant length $(0.5$ or $1.5 \mathrm{~cm})$ and orientation (horizontal or vertical), media strength $(\mathrm{OM}, 1 / 2 \mathrm{OM}, \mathrm{MS}, 1 / 2 \mathrm{MS})$ and the following growth regulators: the anti-auxin 2,3,5-triiodobenzoic acid (TIBA), the cytokinins 6-benzyladenine (BA) and thidiazuron (TDZ), and the growth retardant daminozide $(\mathrm{DM})$. Microcuttings placed vertically on the surface of $\mathrm{OM}, 1 / 2 \mathrm{OM}$ and $1 / 2 \mathrm{MS}$ media without hormones exhibited axillary bud differentiation, but they were swollen and turned brown one month later when placed horizontally on the medium surface. The number of shoots, averaged across OM, 1/2OM and $1 / 2 \mathrm{MS}$ media, was significantly higher from longer (1.5 $\mathrm{cm})$ than shorter $(0.5 \mathrm{~cm})$ microcuttings $\left(4.11\right.$ versus 1.57 shoots microcutting ${ }^{-1}$ ) after 60 days of culture. TIBA or DM at $0.1 \mathrm{mg} \mathrm{l^{-1 }}$ included in OM medium enhanced leaf differentiation, callus induction and formation of adventitious shoots over three months from $0.5 \mathrm{~cm}$ long microcuttings taken from in vitro shoots. The formation of adventitious shoots was sporadic and occurred at a rate of 1 shoot microcutting ${ }^{-1}$ in the presence of $0.1 \mathrm{mg} \mathrm{l}^{-1} \mathrm{DM}$. OM supplemented with $0.1 \mathrm{mg}^{-1}$ TIBA resulted in significantly the highest leaf differentiation (55 leaves microcutting ${ }^{-1}$ ), with a rooting rate of $40 \%$. Contents of phenols, flavonoids and antioxidants were compared for cuttings from young seedlings, callus, in vitro shoots, and seeds. Antioxidant activity was significantly the highest for shoots grown on hormone-free OM medium and callus maintained on OM medium containing $0.1 \mathrm{mg} \mathrm{l}^{-1} 2,4-\mathrm{D}$ (94.7 and $94.3 \%$ inhibition of DPPH free radicals, respectively). Thus, different routes for in vitro regeneration of $J$. phoenicea can be of potential use for many biotechnological, pharmaceutical and food industry applications.
\end{abstract}

Keywords: adventitious shoots, antioxidant potential, flavonoids and phenolics, Juniperus phoenicea, rooting ability. Abbreviations: 2,4-D_2,4-dichlorophenoxyacetic acid; BA_6-benzyladenine; DM_ daminozide; DPPH_2,2-diphenyl-1picrylhydrazyl; IBA_indole-3-butyric acid; mg GAE/100g_gallic acid equivalents; MS_Murashige and Skoog; NAA_ $\alpha$-naphthalene acetic acid; OM_Rugini Olive medium; TDZ_thidiazuron; TIBA_2,3,5-triiodobenzoic acid.

\section{Introduction}

Juniperus phoenicea is a shrub from the family Cupressaceae that grows in arid regions with low winter temperatures and high irradiation in summer (Baquedano and Castillo, 2007; El-bana et al., 2010). It is endemic to regions of the Mediterranean basin and populates North Africa and Canary Islands. Species from the genus Juniperus can be found in single or mixed stands in Portugal, Morocco, Algeria, Tunisia, Egypt, Saudi Arabia and Jordan (Adams, 2004; Meloni et al., 2006; El-Bana et al., 2010; Al-Ramamneh et al., 2012; Medini et al., 2013). In south Jordan, they grow as highland forests, distributed from Tafilah to Wadi Mousa (Syouf and Duwayri, 1995; Al-Ramamneh et al., 2012). Juniper forests are exploited for timber, while berries are used as a spice for flavoring food (Berhe and Negash, 1998;
Loizzo et al., 2007). Their hardy nature and drought tolerance make junipers a good choice as ornamental plants (Loureiro et al., 2007; Kentelky, 2011).

The pharmaceutical attributes of J. phoenicea and its use in traditional medicine are well documented. Extracts from leaves and berries are used to treat diarrhea, rheumatism, bronco-pulmonary symptoms and diabetes (Bellakhder, 1997; Allali et al., 2008). Leaf extracts of J. phoenicea can improve liver and kidney functions, and are potentially useful in ameliorating hepatotoxicity (Ali et al., 2010). Antioxidant activity is also reported in extracts of $J$. phoenicea, possibly owing to its content of phenols, sterols and flavonoids (Medini et al., 2013). Because of the importance of the genus, as mentioned above, attempts have been made in many parts 
of the world to restore juniper forests (Negussie, 1997; Castro et al., 2011; Al-Ramamneh et al., 2012). This objective is however challenged by the recalcitrant nature of many of its species. In this context, regeneration of Juniperus species through seed germination is often poor and unreliable (Wesche et al., 2005; Al-Ramamneh et al., 2012). This is due to insufficient pollination, pest-infested cones, and the low percent of viable and mature seeds at harvest (García, 1998; Ortiz et al., 1998; Wesche et al., 2005). Vegetative propagation by stem cuttings has been reported in $J$. horizontalis, J. squamata and J. virginiana (Kentelky, 2011). Stem cutting propagation of J. phoenicea under greenhouse conditions was attempted in our institute (unpublished results) with a success rate not exceeding $5 \%$.

Tissue culture can be a promising alternative for propagating recalcitrant plant species. J. phoenicea was micropropagated in vitro using explants prepared from adult trees as well as young seedlings (Loureiro et al., 2007; AlRamamneh et al., 2012). These studies have shown that MS medium (Murashige and Skoog, 1962) without hormones is inefficient for the in vitro propagation of $J$. phoenicea, resulting in browning and necrotic areas in the explants. OM medium (Rugini, 1984), in contrast to MS medium, stimulated axillary bud differentiation and development of new branches when used alone or supplemented with hormones: cytokinins ( 0.2 to $0.5 \mathrm{mg} \mathrm{l}^{-1}$ kinetin; 0.1 to $0.2 \mathrm{mg}$ $\left.\mathrm{l}^{-1} \mathrm{BA}, 0.5 \mathrm{mg} \mathrm{l}^{-1} \mathrm{TDZ}\right)$ and auxin $\left(0.5 \mathrm{mg} \mathrm{l}^{-1} \mathrm{NAA}\right)$ (Loureiro et al., 2007; Al-Ramamneh et al., 2012). Loureiro et al. (2007) reported that $40 \%$ of in vitro shoots of J. phoenicea rooted when exposed to $0.5 \mathrm{mg} \mathrm{l}^{-1}$ IBA for $5 \mathrm{~min}$ and then transferred to hormone-free OM medium.

Previous reports on the in vitro plant regeneration of $J$. phoenicea have focused on axillary bud proliferation from microcuttings. Although these techniques were successful for in vitro regeneration, certain morphogenic responses, such as lack of leaf differentiation, were observed in some cultures when we conducted experiments utilizing plant material collected from different donor plants, locations and/or seasons (unpublished results). Loss of morphogenetic potential, formation of different morphotypes and/or explant hyperhydricity, observed in cultures of J. oxycedrus as well as J. excela and J.phoenicea, can be due to the explants' physiological and/or physical conditions, or attributed to the environment from where the plant material is collected (Gómez and Segura, 1995; Negussie, 1997; Loureiro et al., 2007). Therefore, further development of in vitro regeneration protocols of $J$. phoenicea is needed, not least for transformation studies, where selection pressure can reduce regeneration efficiency. Moreover, indirect morphogenesis (through adventitious shoots or somatic embryos) requires regeneration through a callus phase, where the enhancement of secondary metabolite production could be a goal.

This investigation aimed at testing explant size and position, media strength, and various plant growth regulators (auxins, anti-auxins, cytokinins and growth retardants) in relation to the subsequent in vitro regeneration of $J$. phoenicea. The elongation of shoots from axillary buds as well as the formation of callus and adventitious shoots are described. The capacity of $J$. phoenicea to produce secondary metabolites both in vitro and in vivo, and their antioxidant activity are presented; to our knowledge, this is the first report on in vitro antioxidant production in $J$. phoenicea material, whether from Jordan or elsewhere.

\section{Results} Effect of explants and media strength on shoot
multiplication

\section{Explant position}

Microcutting explants that were placed horizontally on the surface of tested media began to swell and were thick at first. However, one month after establishment, cultures showed necrotic areas and turned brown. In contrast, placing microcuttings vertically on the medium surface promoted axillary bud multiplication, shoot elongation and leaf expansion as shown in the next experiment (Fig. 1a).

\section{Explant length}

MS medium proved to be unsuitable for axillary bud differentiation of $J$. phoenicea, regardless of explant size. Microcuttings on MS did not show any morphogenic response, but rather began to deteriorate three weeks after culture establishment, and were brown by the end of the experiment. However, J. phoenicea showed variable responses to in vitro culture on the other media used (OM, $1 / 2 \mathrm{OM}$ and $1 / 2 \mathrm{MS})$. After one month, $1.5 \mathrm{~cm}$ long microcuttings formed significantly $(p<0.01)$ more new shoots, averaged across responsive media, than $0.5 \mathrm{~cm}$ long microcuttings (2.92 and 1.27 shoots cutting ${ }^{-1}$, respectively). Among combinations of explants length and type of media, the highest significant response $(p<0.01)$ was observed for $1.5 \mathrm{~cm}$ long microcuttings grown on $\mathrm{OM}$ and $1 / 2 \mathrm{MS}$ media (3.7 and 3.6 shoots microcutting ${ }^{-1}$, respectively) (Table 1 ). At this stage, the significantly highest $(p<0.01)$ mean shoot length $(1.66 \mathrm{~cm})$, was observed for $1.5 \mathrm{~cm}$ microcuttings grown on $1 / 2 \mathrm{OM}$ (Table 1). The interaction between microcutting length and type of medium was significant for number of leaves per shoot $(p=0.015)$, but not for number of leaves per microcutting $(p=0.13)$. However, the highest mean number of leaves per shoot and microcutting was recorded for $0.5 \mathrm{~cm}$ long microcuttings grown on $1 / 2 \mathrm{MS}$ medium (19.8 and 21.2, respectively) (Fig. 2a).

Shoot multiplication after two months of culture, averaged across responsive media, was also significantly $(p<0.01)$ higher in 1.5 than $0.5 \mathrm{~cm}$ long microcuttings (4.1 and 1.5 shoots microcutting ${ }^{-1}$, respectively). The highest mean numbers of axillary shoots per $1.5 \mathrm{~cm}$ long microcutting were produced on OM and 1/2MS media (5.5 and 5.4, respectively); significantly $(\mathrm{p}<0.01)$ more than on $1 / 2 \mathrm{OM}$ medium $(1.5$ shoots microcutting ${ }^{-1}$ ) (Table 1 ). In terms of numbers of shoots produced on $0.5 \mathrm{~cm}$ long microcuttings, the three media OM, $1 \frac{2}{2} \mathrm{OM}$ and $1 / 2 \mathrm{MS}$, did not differ significantly from each other at this stage $(1.9,1.5$ and 1.3 shoots microcutting 1 , respectively) (Table 1$)$. The significantly $(p<0.01)$ most effective treatment for inducing the highest mean shoot length $(1.5 \mathrm{~cm})$, was obtained using $1.5 \mathrm{~cm}$ microcuttings on $1 / 2 \mathrm{OM}$ (Table 1). However, this treatment was at the same level of significance as using $0.5 \mathrm{~cm}$ microcuttings on $\mathrm{OM}$, $1 / 2 \mathrm{OM}$ and $1 / 2 \mathrm{MS}$ media, where mean shoot length was $1.2,1.1$ and $1.2 \mathrm{~cm}$, respectively (Table 1). Formation of leaves, averaged across responsive media, was favored by 0.5 over $1.5 \mathrm{~cm}$ long microcuttings $(21.4$ versus 16.7 leaves microcutting $^{-1}(p=0.03)$ and 15.3 versus 7.8 leaves shoot ${ }^{-1}$ $(p<0.01)$, respectively). The highest mean number of leaves per shoot and microcuttings $(p<0.01)$ was observed in $0.5 \mathrm{~cm}$ long microcuttings grown on $1 / 2 \mathrm{MS}$ medium (19.6 and 24.9, respectively) (Fig. 2b). 
Table 1. Effects of media type and explant length on in vitro axillary shoot proliferation of Juniperus phoenicea. Explants were excised from small seedlings and data were recorded one and two months after culture establishment.

\begin{tabular}{|c|c|c|c|c|c|c|c|}
\hline \multirow[t]{2}{*}{$\begin{array}{l}\text { Explant } \\
\text { length } \\
(\mathrm{cm})\end{array}$} & \multirow{2}{*}{$\begin{array}{c}\text { Type of media } \\
\text { Culture time (days) }\end{array}$} & \multicolumn{2}{|c|}{$\begin{array}{l}\text { Explants } \\
\text { forming } \\
\text { shoots\% }\end{array}$} & \multicolumn{2}{|c|}{$\begin{array}{l}\text { Average number of } \\
\text { shoots/explant }\end{array}$} & \multicolumn{2}{|c|}{$\begin{array}{l}\text { Average shoot } \\
\text { length }(\mathrm{cm})\end{array}$} \\
\hline & & 30 & 60 & 30 & 60 & 30 & 60 \\
\hline \multirow[t]{3}{*}{1.5} & $\mathrm{OM}$ & 100 & 93 & $3.71 \pm 0.71 \mathrm{a}$ & $5.47 \pm 0.50 \mathrm{a}$ & $0.87 \pm 0.11 \mathrm{~b}$ & $0.61 \pm 0.04 \mathrm{c}$ \\
\hline & $0.5 \mathrm{OM}$ & 100 & 100 & $1.50 \pm 0.19 b$ & $1.45 \pm 0.20 \mathrm{~b}$ & $1.66 \pm 0.10 \mathrm{a}$ & $1.48 \pm 0.10 \mathrm{a}$ \\
\hline & $0.5 \mathrm{MS}$ & 90 & 89 & $3.57 \pm 0.89 \mathrm{a}$ & $5.43 \pm 0.48 \mathrm{a}$ & $0.84 \pm 0.07 \mathrm{~b}$ & $0.76 \pm 0.07 b c$ \\
\hline \multirow[t]{3}{*}{0.5} & OM & 100 & 91 & $1.45 \pm 0.17 \mathrm{~b}$ & $1.90 \pm 0.18 \mathrm{~b}$ & $1.09 \pm 0.07 \mathrm{~b}$ & $1.23 \pm 0.07 \mathrm{ab}$ \\
\hline & $0.5 \mathrm{OM}$ & 100 & 100 & $1.15 \pm 0.12 b$ & $1.50 \pm 0.23 \mathrm{~b}$ & $1.07 \pm 0.10 \mathrm{~b}$ & $1.14 \pm 0.12 \mathrm{abc}$ \\
\hline & $0.5 \mathrm{MS}$ & 90 & 80 & $1.22 \pm 0.15 b$ & $1.33 \pm 0.24 b$ & $1.01 \pm 0.14 \mathrm{~b}$ & $1.18 \pm 0.0 .21 \mathrm{abc}$ \\
\hline Explant (A) & & & & $* *$ & $* *$ & $\mathrm{~ns}$ & $*$ \\
\hline Media (B) & & & & ** & $* *$ & $* *$ & ** \\
\hline $\mathrm{AxB}$ & & & & $* *$ & $* *$ & $* *$ & $* *$ \\
\hline
\end{tabular}

Means followed by the same number are not significantly different at $\mathrm{p} \leq 0.05$ according to Tukey-Kramer Range Test. The results are the mean \pm standard error. ns: notsignificant
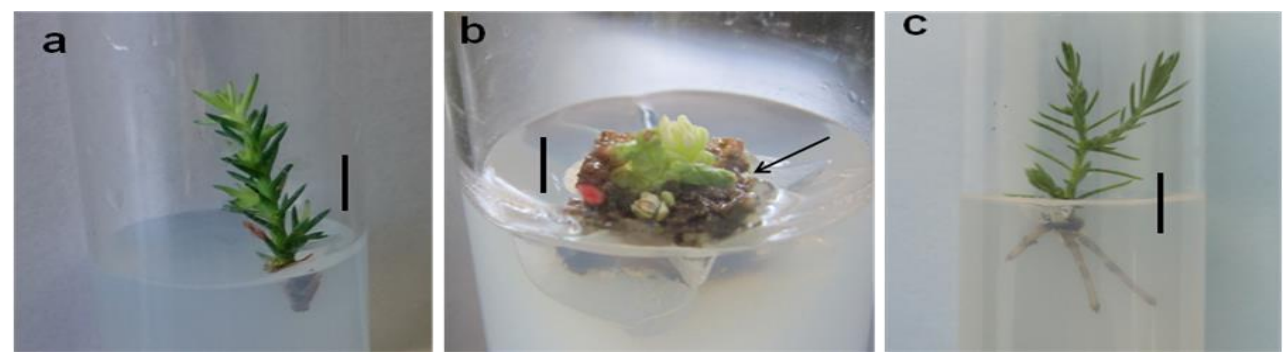

Fig 1. In vitro regeneration of $J$. phoenicea. (a) Elongation of shoots from axillary buds, two months after culturing on $1 / 2$ OM medium (bar $=0.5 \mathrm{~cm}$ ); (b) Adventitious shoots (arrow) formed after three months from shoot-derived callus $($ bar $=0.7 \mathrm{~cm})$ on OM medium supplemented with $0.1 \mathrm{mg} \mathrm{l}^{-1}$ daminozide; (c) Roots formed on OM supplemented with $0.1 \mathrm{mg}^{-1}$ TIBA three months after initiation, (bar $=0.5 \mathrm{~cm})$.

Table 2. Effects of OM medium supplemented with DM, TDZ, BA and TIBA at $0.1 \mathrm{mg}^{-1}$ on in vitro morphogenesis of J. phoenicea, three months after culture establishment.

\begin{tabular}{lccccccc}
\hline $\begin{array}{l}\text { Growth } \\
\text { regulator } \\
\left(\mathrm{mg} \mathrm{l}^{-1}\right)\end{array}$ & $\begin{array}{c}\text { Explants } \\
\text { forming } \\
\text { shoots } \%\end{array}$ & $\begin{array}{c}\text { Shoots/explant } \\
\text { DM }\end{array}$ & $\begin{array}{c}\text { No. axillary } \\
\text { shoots/explant }\end{array}$ & $\begin{array}{c}\text { No. } \\
\text { adventitious } \\
\text { shoots/explant }\end{array}$ & $\begin{array}{c}\text { Mean shoot } \\
\text { length }(\mathrm{cm})\end{array}$ & $\begin{array}{c}\text { Explants } \\
\text { forming } \\
\text { roots } \%\end{array}$ & $\begin{array}{c}\text { Explants } \\
\text { forming } \\
\text { callus } \%\end{array}$ \\
\hline TDZ & 100 & $2.35 \pm 0.53 \mathrm{a}$ & $1.35 \pm 0.21 \mathrm{~b}$ & $1.00 \pm 0.54 \mathrm{a}$ & $0.89 \pm 0.09 \mathrm{~b}$ & 5.9 & 70 \\
$\mathrm{BA}$ & 100 & $1.00 \pm 0.00 \mathrm{~b}$ & $1.00 \pm 0.00 \mathrm{~b}$ & 0.00 & $1.23 \pm 0.13 \mathrm{a}$ & 0.0 & 50 \\
TIBA & 100 & $1.09 \pm 0.09 \mathrm{~b}$ & $1.09 \pm 0.09 \mathrm{~b}$ & 0.00 & $1.42 \pm 0.13 \mathrm{a}$ & 0.0 & 42 \\
\hline
\end{tabular}

Means followed by the same number are not significantly different at $\mathrm{p} \leq 0.05$. The results are the mean \pm standard error

\section{Effects of growth regulators on in vitro morphogenesis}

The effects of growth regulators were highly significant $(p<0.01)$ for the mean number of both axillary shoots and total shoots produced per $0.5 \mathrm{~cm}$ long microcutting explants. It was possible to induce adventitious shoots and rooting in microcuttings grown on OM medium supplemented with DM and TIBA at $0.1 \mathrm{mg} \mathrm{l}^{-1}$ (Figs. 1b-c and Table 2), although the effects of adding growth regulators were not significant $(p>0.05)$. The addition of BA (cytokinin) or TDZ (cytokininlike growth regulator) at $0.1 \mathrm{mg} \mathrm{l}^{-1}$ to $\mathrm{OM}$ medium was not efficient for root formation or induction of adventitious shoots on explants (Table 2). The formation of adventitious shoots was sporadic, and in the presence of $0.1 \mathrm{mg} \mathrm{l}^{-1} \mathrm{DM}$, 1.0 adventitious shoot formed per microcutting on a total of 17 explants (Table 2). However, only five adventitious shoots formed on a total of 20 explants grown on medium treated with $0.1 \mathrm{mg} \mathrm{l}^{-1}$ TIBA (Table 2). All growth regulators used have promoted axillary shoot differentiation, with the highest response being recorded in the presence of DM and TIBA at
$0.1 \mathrm{mg} \mathrm{l}^{-1}$ (1.4 and 3.0 axillary shoots micrcutting ${ }^{-1}$, respectively) (Table 2). Likewise, the mean number of total shoots was significantly higher for medium supplemented with TIBA or DM at $0.1 \mathrm{mg}^{-1}$ (3.2 and 2.4 shoots microcutting $^{-1}$, respectively), than those for OM medium supplemented with TDZ or BA at $0.1 \mathrm{mg} \mathrm{l}^{-1}$ (1.0 and 1.1 shoots microcutting ${ }^{-1}$, respectively). Forty percent of microcuttings grown on medium supplemented with $0.1 \mathrm{mg} \mathrm{l}^{-}$ 1 TIBA formed roots, compared to only $6 \%$ on medium supplemented with $0.1 \mathrm{mg} \mathrm{l}^{-1} \mathrm{DM}$ (Table 2). The highest mean shoot length $(p<0.01)$ was recorded for microcuttings grown on $0.1 \mathrm{mg} \mathrm{l}^{-1} \mathrm{BA}(1.4 \mathrm{~cm})$, whereas shoots grown on $0.1 \mathrm{mg}^{-1} \mathrm{DM}$ showed the least mean shoot length $(0.9 \mathrm{~cm})$ (Table 2). Explants grown on medium containing $0.1 \mathrm{mg} \mathrm{l}^{-1}$ BA produced the highest $(p<0.05)$ mean number of leaves per shoot (24.5) (Fig. 3). The results showed clearly the outstanding performance of TIBA in significantly $(p<0.01)$ stimulating leaf differentiation per explants (55 leaves microcutting ${ }^{-1}$ ), which was approximately two to three times higher than that induced by other treatments (20-27 leaves 


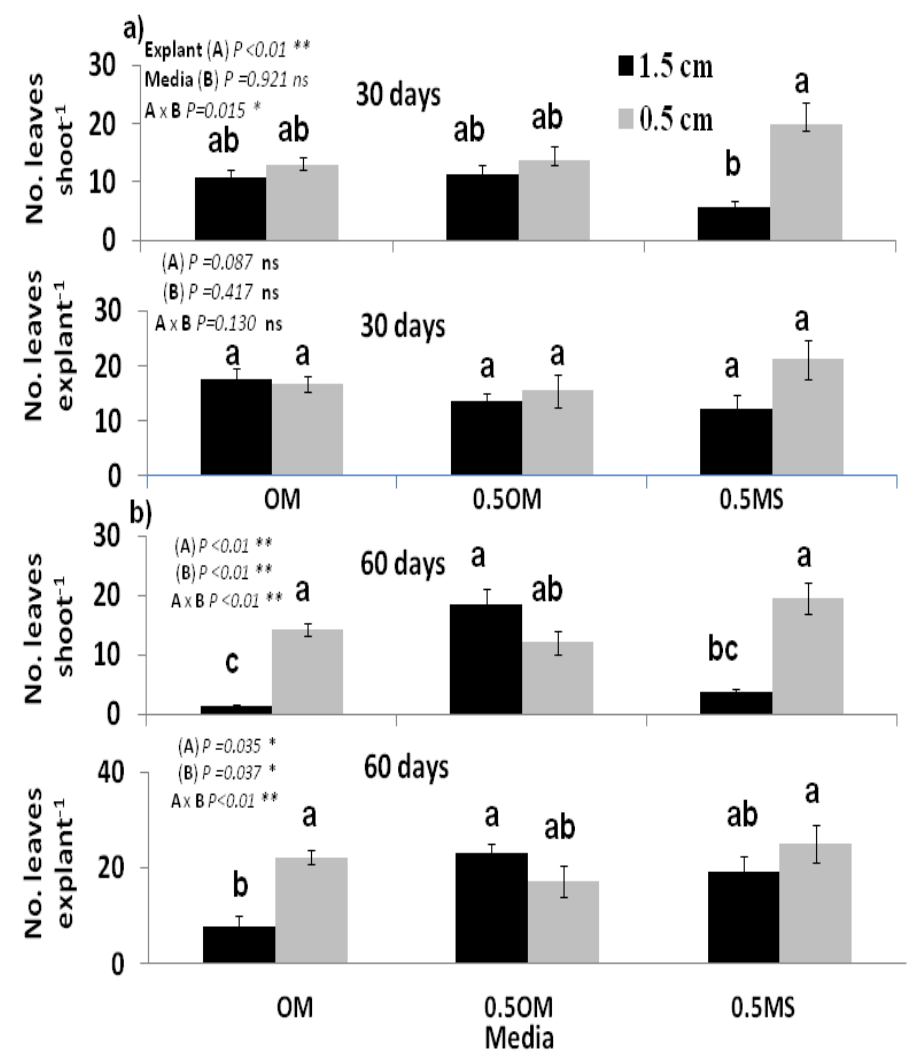

Fig 2. The combined effects of media type (OM, 0.5OM and 0.5MS) and explant length $(0.5 \mathrm{vs.} 1.5 \mathrm{~cm}$ long microcuttings) on leaf differentiation of $J$. phoenicea one and two months after culture establishment. Means of columns in horizontal direction that are followed by the same numbers are not significantly different at $p \leq 0.05$ (ns) according to the Tukey-Kramer Range Test. Significant differences between means was expressed as $* p<0.05$ and $* * p<0.01$

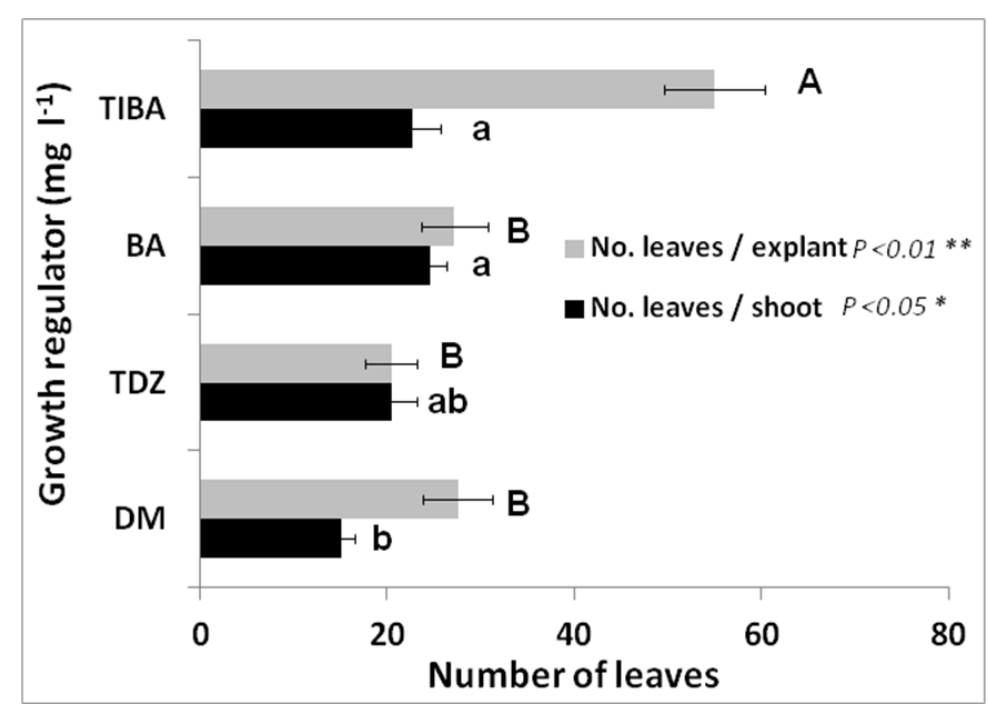

Fig 3. Leaf differentiation of $J$. phoenicea on OM medium supplemented with DM, TDZ, BA or TIBA at 0.1 mg ${ }^{-1}$, three months after culture establishment. Mean separation was represented by uppercase letters for number of leaves per explant, whereas it was represented by lowercase letters for number of leaves per shoot. Means of columns in downward direction that are followed by the same numbers are not significantly different at $p \leq 0.05$. Significant differences between means was expressed as $* p<0.05$ and $* *$ $p<0.01$ 


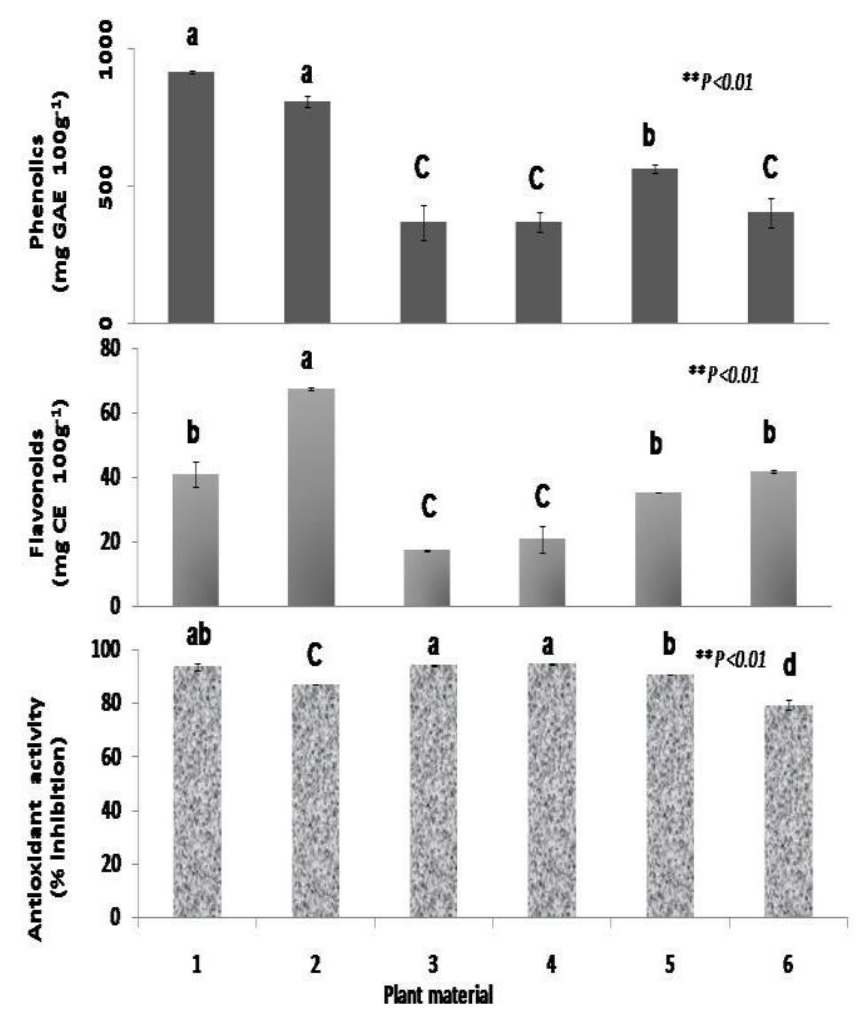

Fig 4. The content of phenols and flavonoids and the antioxidant activity of $J$. phoenicea plant material extracts. 1: Cuttings collected from young seedlings of $J$. phoenicea; 2 . and 3: Callus pieces from $\mathrm{C} 1$ and $\mathrm{C} 2$ media-culture conditions. Callus in $\mathrm{C} 1$ was grown in light at $23 \pm 2{ }^{\circ} \mathrm{C}$, whereas callus in $\mathrm{C} 2$ was grown in darkness at $20 \pm 2{ }^{\circ} \mathrm{C}$. Both types of callus were grown five months on the specified media; 4: In vitro shoots grown on hormone-free OM medium; 5: Newly harvested seeds of J. phoenicea; 6: Seeds of $J$. phoenicea harvested from Shouback and dry-stored at room temperature for two years.

microcutting $^{-1}$ ) (Fig. 3). Callus formation was evident in all cultures, and the frequency of explants forming callus was in the range of $42-70 \%$ (Table 2). Rooted shoots grown on TIBA- supplemented medium and transferred to the greenhouse showed a survival rate of $63 \%$.

\section{Secondary metabolites and antioxidant activity determination}

The content of total phenols and total flavonoids as well as antioxidant activity measured in various plant materials of $J$. phoenicea are shown in Fig. 4. The significantly $(p<0.01)$

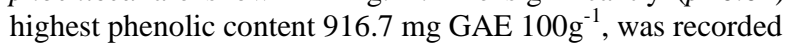
for extracts from cuttings of three-year-old seedlings, which was at the same level of significance as that of C1-type callus pieces, $808.7 \mathrm{mg}$ GAE $100 \mathrm{~g}^{-1}$. The least production of phenolics was observed in extracts of C2-type callus, in vitro shoots and in two-year dry stored seeds (368.6, 368.6 and $403.7 \mathrm{mg}$ GAE $100 \mathrm{~g}^{-1}$, respectively). Flavonoid content significantly $(p<0.01)$ peaked in C1-type callus $(67.6 \mathrm{mg} \mathrm{CE}$ $\left.100 \mathrm{~g}^{-1}\right)$ and was the least in C2-type callus and in vitro shoots

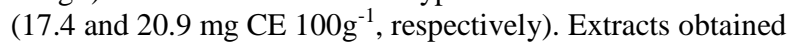
from cuttings of small seedlings, new harvested seeds and that of two-year dry stored seeds were on the same level of significance for flavonoid content $(40.9,35.3$ and $41.7 \mathrm{mg}$ CE $100 \mathrm{~g}^{-1}$, respectively) and ranked second after C1-type callus. The reduction of DPPH radicals by different extract types was in the range of $79.5 \%$ to $94.7 \%$ (Fig. 4). The results showed that $\mathrm{C} 2$-type callus and in vitro shoots exhibited the significantly $(p<0.01)$ highest radical scavenging activity as indicated by their inhibition of the DPPH free radicals ( 94.3 and $94.7 \%$, respectively). The extracts of cuttings obtained from three years old seedlings showed also a good antioxidant activity, with DPPH free radicals inhibition of $93.7 \%$, and were on the same level of significance as that exhibited by in vitro callus and shoots. The least antiradical activity $(p<0.01)$ was evident in extracts of two-year dry stored seeds $(79.5 \%)$. The antioxidant activity as measured showed no relationship with the total contents of phenolics and flavonoids.

\section{Discussion}

These results have shown that explant length and position, type of medium, and growth regulators played a major role in the morphogenic response of J. phoenicea in vitro cultures.

\section{Effects of explant (size, orientation) and media strength}

The swelling observed in the explants placed horizontally on the surface of the media is probably due to a higher contact surface with the medium and thus exposure to more nutrients and water compared to explants placed vertically, which rather promoted axillary bud differentiation. In partial agreement with the present findings, Debnath (2005) reported the swelling of Vaccinium vitis-idaea cuttings placed horizontally on the medium surface. Horizontal orientation of explants encouraged shoot proliferation in a number of 
woody plant species including Amelanchier spicata, Acer rubrum L., Forsythia $x$ intermedia Zab, Mallus $x$ domestica Borkh, Betula nigra L. and Pyrus communis L. (Lane, 1979; McClelland and Smith, 1990). In the present investigation, although initial swelling occurred for explants that were placed horizontally, shoot differentiation was not observed, possibly owing to the lack of growth regulators in media used for this experiment, which were full strength versus half strength MS- and OM-based media. However, such media in our study could promote axillary bud differentiation in explants placed vertically, consistent with earlier studies concerning $J$. phoenicea in vitro regeneration (Loureiro et al., 2007; Al-Ramamneh et al., 2012). It can be assumed that the small surface area where vertical cuttings came into contact with the above-mentioned media has created a more favorable environment, in the absence of growth regulators, for a better utilization of nutrients than is the case for horizontally orientated explants. The reduced contact of explants to medium could ameliorate the rich nutrient component of the medium and thus can result in a morphogenic response like the early development of shoots observed on the sides of $J$. excelsa cotyledons that were not in direct contact with the media (Negussie, 1997).

The lack of response of cultured explants on MS compared to $\mathrm{OM}, 1 / 2 \mathrm{OM}$ and $1 / 2 \mathrm{MS}$ could be attributed to the media constituents. The striking difference between MS and OM is their content of nitrogen and in particular the $\mathrm{NH}_{4}+$ and $\mathrm{NO}_{3}$ forms. The content of nitrogen supplemented in $\mathrm{OM}$ as $\mathrm{NH}_{4} \mathrm{NO}_{3}$ and $\mathrm{KNO}_{3}$ is equal to $24 \%$ and $57 \%$ to that in MS, respectively. Therefore, the reduction of total nitrogen in $\mathrm{OM}, 1 / 2 \mathrm{OM}$ and $1 / 2 \mathrm{MS}$ may have contributed to the enhanced response observed in media other than MS. These results are in agreement with those reported earlier for the in vitro cultures of $J$. phoenicea and other woody plants, in which sensitivity to MS supplemented with full strength salts was observed (Perez-Bermudez and Sommer, 1987; Bonga and Von Aderkas, 1992; Loureiro et al., 2007; Al-Ramamneh et al., 2012). It is not only the reduction of total nitrogen but also the optimal ammonium/nitrate balance that had an influence on cell fate in Juniperus excelsa in vitro cultures (Shanjani, 2003). According to that study, using half strength inorganic nitrogen in MS has promoted callus production without obvious organ differentiation. The formation of adventitious shoots and the growth of lateral buds was possible in $J$. excelsa when MS was devoid of $\mathrm{NH}_{4} \mathrm{NO}_{3}$ (Shanjani, 2003).

Differentiation of shoots and leaves of $J$. phoenicea in vitro cultures was affected by explant size and media strength. Larger explants $(1.5 \mathrm{~cm})$ encouraged the growth of more axillary shoots, possibly due to their higher content of food reserves than those of smaller explants $(0.5 \mathrm{~cm})$, as indicated by Pierik (1997). On the other hand, the differentiation of leaves was stimulated by smaller explants. In agreement with the present findings, Fayek et al., (2009) reported a significant increase in the number of axillary shoots of Vitis vinifera in response to an increase in explant size from 0.5 $\mathrm{mm}$ to $1.0 \mathrm{~mm}$. Moreover, explants between one and three $\mathrm{cm}$ prepared from shoot tips of species from Cryptomeria, Sequoia and Chamaecyparis genera of the Cupressaceae family gave better results compared to smaller explants (Isikawa, 1987; Ball, 1987; Kurz, 1989). In general, the effect of explant size on regeneration in plants is well documented (Mazri, 2013; Rehman, 2014; Plaza-Wüthrich et al., 2015). In the present study, the main effects of the three media averaged across explant size, indicated a contrasting response of the number of axillary shoots formed and mean shoot length. The use of OM and $1 / 2$ MS had significantly increased the number of axillary shoots compared to $1 / 2 \mathrm{OM}$, and the opposite was shown for shoot length. These growth patterns indicated a differential partitioning of assimilates in response to explant size and media strength.

\section{Effects of growth regulators on in vitro morphogenesis}

Cell fate and organ differentiation were both influenced by the type of growth regulator (Fig. 3 and Table 2). Significantly higher shoot formation per $0.5 \mathrm{~cm}$ length explants was observed on OM supplemented with DM (2.4) and TIBA (3.2) at $0.1 \mathrm{mg} \mathrm{l}^{-}$as compared to explants treated with $0.1 \mathrm{mg} \mathrm{l}^{-} \mathrm{TDZ}$ (1.0) or BA (1.1), where the latter (TDZ and $\mathrm{BA}$ ) promoted the significantly highest shoot length (1.2 and $1.4 \mathrm{~cm}$, respectively) (Table 2). The highest average number of leaves per explant, 55, was recorded on TIBA (Fig. 3), whereas DM and TIBA were successful in inducing adventitious shoots and root formation (Table 2). This was not the case for TDZ and BA, where axillary shoot multiplication occurred with no signs of rooting (Table 2). The highest incidence of callus formation was recorded using DM (Table 2).

As revealed by the present investigation, when explants were grown for three months on media containing DM (growth retardant), TIBA (anti-auxin), and BA or TDZ (cytokinins) various morphological responses were obtained. It is assumed that members of the Cupressaceae family have low cytokinin requirements (Negussie, 1997), and, thus, the formation of axillary shoots was evident in all cultures (Table 2). Micropropagation by axillary shoot multiplication is typical for Juniperus species and has been adopted by many researchers (Gómez and Segura, 1995; Loureiro et al., 2007; Castro et al., 2011; Zaidi et al., 2012). The procedures involved growing explants normally from adult trees on media with different concentrations of cytokinins and auxins. The specifications for media varied, but among the best for shoot formation were: SH (Schenk and Hildebrandt, 1972) for J. oxycedrus; OM for J. Phoenicea; GD (Gupta and Durzan, 1985) and OM for J. navicularis; and WPM (Lloyd and McCown, 1980) for J. horizontalis, J. excelsa and J. chinensis. Furthermore, Al-Ramamneh et al., (2012) tried micropropagation of $J$. phoenicea using explants excised from young seedlings and found that $\mathrm{OM}$ medium supplemented with $0.5 \mathrm{mg} \mathrm{l}^{-1} \mathrm{TDZ}$ was the best medium/growth regulator combination.

The anti-auxin transport inhibitor TIBA and the growth retardant DM have been utilized in plant tissue culture to adjust the endogenous hormonal balance of in vitro cultured explants, in order to induce a specific differentiation in tissues (Lall et al., 2005; Liao et al., 2008; Kepenek and Karoğlu, 2011). This was supported in the current study by the formation of adventitious shoots and roots in response to TIBA and DM but not cytokinins. TIBA enhanced shoot proliferation in shoot cultures derived from mature trees of Acer and Alnus genera (Marks and Simpson, 1994; Lall et al., 2005). DM promoted shoot formation in a number of plants including Schlumbergera truncata, Rhipsalidopsis gaertneri and Malus domestica (Al-Ramamneh, 2006; Kepenek and Karoğlu, 2011).

Auxin transport inhibitors such as TIBA reduce root formation by preventing auxin efflux (Lomax et al., 1995; Ford et al., 2001; Lall et al., 2005). Auxin patterning and how this influences plant growth and development is still controversial (Van Berkel et al., 2013). The cycling of proteins that act as efflux carriers can influence auxin fluxes or levels. Models for differential source or tissue-specific requirements for flux orientations of auxin include regulation 
by gene expression; and models of auxin action nowadays combine the sink behavior of an auxin maximum for different tissue layers with a flux-based model (Van Berkel et al., 2013). It is possible that TIBA-induced root formation in the current investigation could have resulted from changes in auxin transport with a certain pattern of accumulation and conjugation (Guerrero et al., 1999; Muday, 2001; LudwigMüller, 2011; Dong et al., 2012), which could induce changes at the different levels of auxin patterning mentioned above. Therefore, as auxin transport was initially inhibited by TIBA, this may have amplified the effects of endogenous cytokinins, resulting in more shoot formation than after external application of TDZ or BA. On the other hand, DM-treated explants developed the significantly shortest in vitro shoots, indicating the possible role of DM in negating the effects of endogenous gibberellins. The action of DM as a height growth retardant has been reported by Luoranen et al. (2002), Kim et al. (2010) and Kazemi et al. (2014). In fact, incubation on media containing DM may have contributed to increased cytokinin activity as suggested by Rossini et al. (2005), and could have modulated the ratio of cytokinins to auxins but to a lesser extent than TIBA, owing to the influence of the latter on auxin accumulation. Thus, higher shoot formation induced by TIBA and DM must have resulted in depletion of endogenous cytokinins at a faster rate than that for exogenously applied TDZ or BA. Metabolic turnover during the culture may have eventually increased hydrolysis of auxin conjugates and the availability of auxin to enable rooting from competent cells towards the end of the experiment, an event that was more critical in media initially containing TIBA. Evidence that supports this was recorded on media supplemented with $0.1 \mathrm{mg} \mathrm{l}^{-}$TIBA and DM, where root formation was eventually observed. Dong et al. (2012) reported that TIBA could influence the accumulation, spatial distribution and signaling of auxin, which became localized in the root tip of poplar hybrid 741 toward the onset of rhizogenesis. The expression pattern of auxin conjugate synthetases and hydrolases was reported in many plants and suggested their overlapping roles in the development of plant organs (Ludwig-Müller, 2011). It is also possible that exogenously applied cytokinins did not induce the expression of tissue-specific auxin carriers necessary for an auxin maximum for the tissue threshold of rooting competence as a specific auxin pattern (Stoma et al., 2008) in comparison to the effects induced by TIBA and DM. The promoting effects of TIBA and DM on shoot and root formation, in addition to callus induction, could be beneficial for the study of the developmental biology of plant organs in relation to the action of hormones in general and of auxins in particular.

\section{Secondary metabolites and antioxidant activity}

The presence of phenolics, flavonoids and a significant antioxidant activity in methanolic extracts of different plant materials of Jordanian J. phoenicea were confirmed by the results of the current investigation. This is in accord with similar reports for juniper species from other regions (Elmastaş et al., 2006; Moein et al., 2010; Emami et al., 2011; Höferl et al., 2014; Cioanca et al., 2015; Elmhdwi et al., 2015). However, antioxidant activity as reported in this study did not correlate with the total content of phenolics and flavonoids, except for extracts obtained from cuttings of small seedlings, which shared the highest antioxidant activity with that of C2-type callus and in vitro shoots. It is noteworthy that cuttings of small seedlings had the significantly highest phenol content and ranked second in their content of flavonoids. Moreover, C2-type callus and in vitro shoots showed the significantly highest antioxidant activity and the lowest phenol and flavonoid contents. It could be that extraction with methanol was not the optimal choice. Elmhdwi et al. (2015) showed that extraction of total phenols and flavonoids with $70 \%$ acetone in J. phoenicea gave better results than with $70 \%$ methanol or ethanol. They further elaborated that $70 \%$ acetone was more suitable for scavenging activity determination in $J$. phoenicea which resulted in higher reducing power. This discrepancy between antioxidant activity and total phenol content was also reported for extracts of $J$. oxycedrus subsp. oxycedrus and was explained by the nature of compounds contributing to the observed antioxidant activity (Chaouche et al., 2013). Plant material tested here included vegetative material (shoots from greenhouse grown seedlings) and seeds (newly harvested versus two years dry stored), in addition to in vitro material (C1 and C2 type callus, micro-shoots). Thus, active constituents in extracts of such diverse plant materials are most likely different and reflected different metabolic pathways. Phenolics in low amounts in plant extracts can contribute to antioxidant activity in a synergistic manner with other non-phenolic molecules (Chaouche et al., 2013). Hence, the nature of such molecules, their chemical structure and degree of polymerisation can protect cells from oxidative damage (Oszmianski et al., 2007).

Explants grown in vitro, such as shoots and callus, are presumably undergoing stress as they are separated from the mother plant and grown in a confined, although nutritive environment. Alguacil et al. (2006) pointed out for $J$. oxycedrus $\mathrm{L}$. that a stressful environment can increase the activity of antioxidant enzymes such as superoxide dismutase and total peroxidase, which are considered an antioxidant system in plants. C1-type callus was high in its content of both phenol and flavonoids but ranked third in its antioxidant activity as compared to C2-type callus, which ranked first as an antioxidant. The two type of callus were grown under different illumination conditions (light for C1-type callus and darkness for C2-type callus) and on media containing different growth regulators (C1-type callus on $0.1 \mathrm{mg} \mathrm{l}^{-1}$ TDZ, C2-type callus on $0.1 \mathrm{mg} \mathrm{l}^{-1}$ 2,4-D), which could explain their different antioxidant response.

\section{Materials and methods}

\section{Plant material}

Three-year-old seedlings of J. phoenicea were obtained from the Ministry of Agriculture in Shouback city (latitude $30^{\circ} 31^{\prime}$ $\mathrm{N}$, longitude $35^{\circ} 32^{\prime} \mathrm{E}$ ), south of Jordan. Terminal branches approximately $20-30 \mathrm{~cm}$ in length were trimmed in spring from $J$. phoenicea seedlings to serve as the source of microcuttings. Branches were cleaned with tap water for 5 minutes, surface sterilized with sodium hypochlorite $(2.5 \%$ active chlorine) for $10 \mathrm{~min}$, and finally rinsed three times with distilled water. The surface-sterilized plant material was used in the subsequent studies.

\section{Explant (size \& orientation) and media strength}

Disinfected branches were divided into microcuttings of $1.5 \pm$ $0.2 \mathrm{~cm}$ and $0.5 \pm 0.2 \mathrm{~cm}$ in length, respectively. Microcuttings were placed either vertically or horizontally in tubes $(25 \mathrm{~mm} \times 150 \mathrm{~mm})$ on the following media: MS, OM, half strength MS $(1 / 2 \mathrm{MS})$ and half strength OM $(1 / 2 \mathrm{OM})$. Half strength media were prepared as MS or OM supplemented with half concentration of macro- and micro- nutrients. 
Observations were collected one and two months after culture establishment.

\section{Induction of adventitious shoots/roots and callus formation}

\section{Establishment of in vitro cultures}

Another group of disinfected branches were prepared as mentioned earlier and divided into $1.5 \pm 0.2 \mathrm{~cm}$ long microcuttings that were grown on OM medium without hormones. In vitro shoots elongated from axillary buds on the $1.5 \mathrm{~cm}$ long microcuttings were divided after 13 weeks to provide $0.5 \pm 0.1 \mathrm{~cm}$ long microcuttings, which were cultured for 6 months on OM medium supplemented with DM at 0.1 $\mathrm{mg}^{-1}$. Shoot multiplication occurred and provided plant material for the next experiment. Callus formed on cultures maintained on OM supplemented with $0.1 \mathrm{mg} \mathrm{l}^{-1} \mathrm{DM}$ was divided into small pieces and transferred to $\mathrm{OM}$ media, supplemented with TDZ or 2,4-D at $0.1 \mathrm{mg} \mathrm{l}^{-1}$ (media abbreviation: $\mathrm{C} 1$ and $\mathrm{C} 2$, respectively) to be used in the antioxidant assay.

\section{Influence of growth regulators}

Shoots maintained in vitro on $\mathrm{OM}+0.1 \mathrm{mg} \mathrm{l}^{-1} \mathrm{DM}$ were subcultured by dividing them into $0.5 \pm 0.1 \mathrm{~cm}$ long microcuttings that were transferred to $\mathrm{OM}$ medium supplemented with DM, TDZ, BA or TIBA, at $0.1 \mathrm{mg} \mathrm{l}^{-1}$. Observations were collected three months after culture establishment. Rooted shoots were transferred to a greenhouse and grown in pots containing a mixture of peat and perlite in a $3: 2$ ratio.

\section{Secondary metabolite determination}

Plant material used for determination of total phenols, total flavonoids and antioxidant activity was represented by: (1) cuttings collected from young seedlings of J. phoenicea; (2) and (3), callus pieces from $\mathrm{C} 1$ and $\mathrm{C} 2$ culture conditions. Callus in $\mathrm{C} 1$ was grown in light at $23 \pm 2{ }^{\circ} \mathrm{C}$, whereas callus in $\mathrm{C} 2$ was grown in darkness at $20 \pm 2{ }^{\circ} \mathrm{C}$; (4) in vitro shoots grown on hormone-free OM media; (5) freshly harvested seeds of J. phoenicea; and (6) seeds of $J$. phoenicea harvested from Shouback and dry-stored at room temperature for two years.

\section{Total phenolic determination}

The total phenolic content was estimated by the FolinCiocalteu method (Singleton et al., 1999). Total phenolics were calculated from a gallic acid calibration curve and were expressed as gallic acid equivalents (mg GAE/100g).

\section{Total flavonoids determination}

The total flavonoid content was determined as described by Zhishen et al. (1999). Total flavonoid contents were calculated on the basis of the standard curve for (+) catechen hydrate solutions $\left(10 \mathrm{mg} \mathrm{l}^{-1}-200 \mathrm{mg}^{-1}\right)$.

\section{Antioxidant activity determination using DPPH (2,2- diphenyl-1-picrylhydrazyl)}

The antioxidant activity of the samples was determined according to Turkmen et al. (2006). The radical scavenging activity of the tested samples was expressed as \% inhibition of the free radicals according to the following formula:
Inhibition $(\%)=$ (absorbance of control - absorbance of sample) / (absorbance. of control) *100; (Yen and Duh, 1994). Chemicals used for in vitro cultures and determination of secondary metabolites were obtained by United Tetra Group; a supplier of Sigma Aldrich products (Jordan, Amman).

\section{Experimental layout and design}

Observations on shoot and leaf differentiation, as well as on callus and root formation, were recorded for each experiment. Shoot organogenesis defined as the formation of axillary and / or adventitious shoots was monitored. Cultures were maintained at $23 \pm 2{ }^{\circ} \mathrm{C}$ under a $16 / 8$ (light/dark) photoperiod

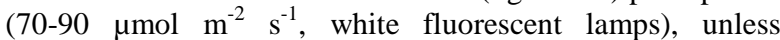
otherwise mentioned. Each experiment was repeated at least twice. A factorial design in a completely randomized arrangement was employed for the study of the effects of medium type and explant length on in vitro axillary shoot proliferation of $J$. phoenicea. The effect of the growth regulators (DM, TDZ, BA and TIBA) on in vitro morphogenesis was studied using a completely randomized design. Data were represented by the mean \pm standard error and analyzed for significance by SAS using the mixed procedure (SAS Institute Inc, Cary, NC). Mean separation was performed according to Tukey-Kramer Range test and treatment means were compared at $p \leq 0.05$ significance level. Means of total phenols, total flavonoids and \% inhibition of free radicals were compared using the LSD test at $5 \%$ significance level.

\section{Conclusion}

The methods described in this report for differentiation of shoots and leaves in $J$. phoenicea complement the available studies for this species, and provide potential ways to overcome the lack of leaf differentiation noticed earlier in some in vitro cultures. Higher numbers of shoots were produced by longer explants $(1.5 \mathrm{~cm})$ than by shorter explants $(0.5 \mathrm{~cm})$. However, differentiation of leaves showed the significantly highest response when in vitro shoots were divided into $0.5 \mathrm{~cm}$ explants and grown on $\mathrm{OM}+0.1 \mathrm{mg} \mathrm{l}^{-}$ TIBA for three months (55 leaves/explant). The ability of explants $(0.5 \mathrm{~cm}$ each $)$ to produce callus and axillary shoot elongation in addition to adventitious shoots and rooting increased with in vitro incubation on OM supplemented with the growth regulators DM or TIBA at $0.1 \mathrm{mg} \mathrm{l}^{-1}$, indicating a possible role for these growth regulators in modulating the ratio of cytokinins to auxins. The present investigation also confirmed the antioxidant activity of Jordanian J. phoenicea which can be important for the pharmaceutical and food industries.

\section{Acknowledgments}

This project was supported by the Deanship of Scientific Research in Al-Balqa Applied University. Additional requirements and instruments were provided by NCARE (National Center of Agricultural Research and Extension). Determination of antioxidant activity was carried out in Labs of Faculty of Agriculture in Jordan University of Science and Technology. The authors would like to thank Dr. David Clapham (SweTree Technologies AB, Sweden), for critical reading of the manuscript and for valuable suggestions.

\section{References}

Adams RP (2004) Junipers of the world: the genus Juniperus. Trafford, Vancouver. 
Alguacil MM, Caravaca F, Díaz-Vivancos P, Hernández JA, Roldán A (2006) Effect of arbuscular mycorrhizae and induced drought stress on antioxidant enzyme and nitrate reductase activities in Juniperus oxycedrus L. grown in a composted sewage sludge-amended semi-arid soil. Plant Soil. 279: 209218.

Ali SA, Rizk MZ, Ibrahim NA, Abdallah MS, Sharara HM, Moustafa MM (2010) Protective role of Juniperus phoenicea and Cupressus sempervirens against $\mathrm{CCl}_{4}$. World $\mathrm{J}$ Gastrointest Pharmacol Ther. 1: 123-131.

Allali H, Benmehdi H, Dib MA, Tabti B, Ghalem S, Benabadji N (2008) Phytotherapy of diabetes in West Algeria. Asian J Chem. 20: 2701-2710.

Al-Ramamneh EA (2006) Somatic embryogenesis and transformation studies in Schlumbergera and Rhipsalidopsis. $\mathrm{PhD}$ Dissertation. University of Hannover, Germany.

Al-Ramamneh EA, Durra S, Daradkeh N (2012) Propagation physiology of Juniperus phoenicea L. from Jordan using seeds and in vitro culture techniques: baseline information for a conservation perspective. Afr J Biotechnol. 11: 7684-7692.

Ball EA (1987) Tissue culture multiplication of Sequoia. In: Bonga JM, Durzan DJ (eds) Cell and tissue culture in forestry. Martinus Nijhoff, Boston pp. 146-158.

Baquedano FJ, Castillo FJ (2007) Drought tolerance in the Mediterranean species Quercus coccifera, Quercus ilex, Pinus halepensis, and Juniperus phoenicea. Photosynthetica. 45: 229-238.

Bellakhder J (1997) La pharmacopee marocaine traditionelle. Ibis Press, Paris.

Berhe D, Negash L (1998) A sexual propagation of Juniperus procera from Ethiopia: a contribution to the conservation of African pencil cedar. Forest Ecol Manag. 112: 179-190.

Bonga JM, Von Aderkas P (1992) In vitro culture of trees. Kluwer Academic Pub, Dordrecht, Boston, London.

Castro MR, Belo AF, Afonso A, Zavattieri MA (2011) Micropropagation of Juniperus navicularis, an endemic and rare species from Portugal SW coast. Plant Growth Regul. 65: 223-230.

Chaouche TM, Haddouchi F, Ksouri R, Medini F, Atik-Bekara F (2013) In vitro evaluation of antioxidant activity of the hydromethanolic extracts of Juniperus oxycedrus subsp. oxycedrus. Phytothérapie. 11: 244-249.

Cioanca O, Hancianu M, Mihasan M, Hritcu L (2015) Antiacetylcholinesterase and antioxidant activities of inhaled juniper oil on amyloid beta (1-42)-induced oxidative stress in the rat hippocampus. Neurochem Res. 40: 952-960.

Debnath SC (2005) Effects of carbon source and concentration on development of lingonberry (Vaccinium vitis-idaea L.) shoots cultivated in vitro from nodal explants. In Vitro Cell Dev Biol. 41: 145-150.

Dong NG, Yin WL, Gao Y, Pei D (2012) Indole-3-acetic acid accumulation during poplar rhizogenesis revealed by immunohistochemistry. Biol Plantarum. 56: 581-584.

El-Bana M, Shaltout K, Khalafallah A, Mosallam H (2010) Ecological status of the Mediterranean Juniperus phoenicea L. relicts in the desert mountains of north Sinai, Egypt. Flora. 205: 171-178.

Elmastaş M, Gülçin İ, Beydemir Ş, Küfrevioğlu Öİ, Aboul-Enein HY (2006) A study on the in vitro antioxidant activity of Juniper (Juniperus communis L.) fruit extracts. Anal Lett. 39: 47-65.

Elmhdwi MF, Attitalla IH, Khan BA (2015) Evaluation of antibacterial activity and antioxidant potential of different extracts from the leaves of Juniperus phoenicea. J Plant Pathol Microb. 6: 1-8.

Emami SA, Asgary S, Naderi GA, Shams Ardekani MR, Kasher T, Aslani S, Airin A, Sahebkar A (2011) Antioxidant activities of Juniperus foetidissima essential oils against several oxidative systems. Rev Bras Farmacogn. 21: 627-634.
Fayek MA, Jomaa AH, Shalaby AA, Al-Dhaher MA (2009) Meristem tip culture for in vitro eradication of grapevine leaf roll-associated virus-1 (GLRaV-1) and grapevine fan leaf virus (GFLV) from infected flame seedless grapevine plantlets. Iniciacion a la Investigacion. Available at: http://revistaselectronicas.ujaen.es/index.php/ininv /article/download/303/290. Access: March 14th, 2017.

Ford YN, Bonham EC, Cameron RWF, Blake PS, Judd HL, Harrison-Murray RS (2001) Adventitious rooting: examining the role of auxin in an easy- and a difficult-to-root plant. Plant Growth Regul. 36: 149-159.

García D (1998) Interaction between juniper Juniperus communis L. and its fruit insects: pest abundance, fruit characteristics and seed viability. Acta Oecol. 19: 517-525.

Gómez MP, Segura J (1995) Axillary shoot proliferation in cultures of explants from mature Juniperus oxycedrus trees. Tree Physiol. 15: 625-628.

Guerrero JR, Garrido G, Acosta M, Sánchez-Bravo J (1999) Influence of 2,3,5-triiodobenzoic acid and 1-nnaphthylphthalamic acid on indoleacetic acid transport in carnation cuttings: relationship with rooting. J Plant Growth Regul. 18: 183-190.

Gupta PK, Durzan DJ (1985) Shoot multiplication from mature trees of douglas-fir (Pseudotsuga menziesii) and sugar pine (Pinus lambertiana). Plant Cell Rep. 4: 177-179.

Höferl M, Stoilova I, Schmidt E, Wanner J, Jirovetz L, Trifonova D, Krastev L, Krastanov A (2014) Chemical composition and antioxidant properties of juniper berry (Juniperus communis L.) essential oil. Action of the essential oil on the antioxidant protection of Saccharomyces cerevisiae model organism. Antioxidants. 3: 81-98.

Isikawa $H$ (1987) In vitro culture of cryptomeria callus and organs. In: Bonga JM, Durzan DJ (eds) Cell and tissue culture in forestry. Martinus Nijhoff, Boston pp 109-113.

Kazemi SS, Hashemabadi D, Torkashvand AM, Kaviani B (2014) Effects of cycocel and daminozide on vegetative growth, flowering and the content of essence of pot marigold (Calendula officinalis). Journal of Ornamental Plants. 4: 107114

Kentelky E (2011) The analysis of rooting and growth peculiarities of Juniperus species propagated by cuttings. Bulletin UASVM Horticulture. 68: 380-385.

Kepenek K, Karoğlu Z (2011) The effects of paclobutrazol and daminozide on in vitro micropropagation of some apple (Malus domestica) cultivars and M9-rootstock. Afr J Biotechnol. 10: 4851-4859.

Kim YH, Khan AL, Hamayun M, Kim JT, Lee JH, Hwang IC, Yoon CS, Lee IJ (2010) Effects of prohexadione calcium on growth and gibberellins content of Chrysanthemum morifolium R. cv Monalisa white. Sci Hort. 123: 423-427.

Kurz MPL (1989) Micropropagation of yellow cypress (Chamaecyparis nootkatensis) by adventitious and axillary shoot multiplication. MSc Dissertation. Simon Fraser University.

Lall S, Mandegaran Z, Roberts AV (2005) Shoot multiplication in cultures of mature Alnus glutinosa. Plant Cell Tiss Organ Cult. 83: 347-350.

Lane WD (1979) Regeneration of pear plants from shoot meristem-tips. Plant Sci Lett. 16: 337-342.

Liao YK, Liao CK, Ho YL (2008) Maturation of somatic embryos in two embryogenic cultures of Picea morrisonicola Hayata as affected by alternation of endogenous IAA content. Plant Cell Tiss Organ Cult. 93: 257-268.

Lloyd G, McCown B (1980) Commercially feasible micropropagation of mountain laurel, Kalmia latifolia by use of shoot tip culture. Proc Int Comb Plant Prop Soc. 30: 421427.

Loizzo MR, Tundis R, Conforti F, Saab AM, Statti GA, Menichini F (2007) Comparative chemical composition, antioxidant and hypoglycaemic activities of Juniperus 
oxycedrus ssp. oxycedrus L. berry and wood oils from Lebanon. Food Chem. 105: 572-578.

Lomax TL, Muday GK, Rubery PH (1995) Auxin transport. In: Davis PJ (ed) Plant hormones. Kluwer Academic Publishers, Netherlands pp 509-530.

Loureiro J, Capelo A, Brito G, Rodriguez E, Silva S, Pinto G, Santos C (2007) Micropropagation of Juniperus phoenicea from adult plant explants and analysis of ploidy stability using flow cytometry. Biol Plantarum. 51: 7-14

Ludwig-Müller J (2011) Auxin conjugates: their role for plant development and in the evolution of land plants. J Exp Bot. 62: 1757-1773.

Luoranen J, Rikala R, Aphalo PJ (2002) Effects of CCC and daminozide on growth of silver birch container seedlings during three years after spraying. New Forest. 23: 71-80.

Marks TR, Simpson SE (1994) Factors affecting shoot development in apically dominant Acer cultivars in vitro. $\mathrm{J}$ Hortic Sci. 69: 543-537.

Mazri MA (2013) Effect of basal medium, explants size and density on the in vitro proliferation and growth of date palm (Phoenix dactylifera L.) cultivar '16-bis'. Not Sci Biol. 5: 332337.

McClelland MT, Smith MAL (1990) Vessel type, closure, and explant orientation influence in vitro performance of five woody species. HortScience. 25: 797-800.

Medini H, Elaissi A, Khouja ML, Chemli R (2013) Phytochemical screening and antioxidant activity of Juniperus phoenicea ssp. phoenicea L. extracts from two Tunisian locations. Journal of Experimental Biology and Agricultural Sciences. 1: 77-82.

Meloni M, Ferini D, Filigheddu R, Binelli G (2006) Genetic variation in five Mediterranean populations of Juniperus phoenicea revealed by inter-simple sequence repeat (ISSR) markers. Ann Bot. 97: 299-304

Moein MR, Ghasemi Y, Moein S, Nejati M (2010) Analysis of antimicrobial, antifungal and antioxidant activities of Juniperus excelsa M. B subsp. Polycarpos (K. Koch) Takhtajan essential oil. Pharmacognosy Res. 2: 128-131.

Muday GK (2001) Auxins and tropisms. J Plant Growth Regul. 20: $226-243$.

Murashige T, Skoog F (1962) A revised medium for rapid growth and bioassays with tobacco tissue cultures. Physiol Plant. 15: 473-497.

Negussie A (1997) In vitro induction of multiple buds in tissue culture of Juniperus excelsa. Forest Ecol Manag. 98: 115-123.

Ortiz PL, Arista M, Talavera S (1998) Low reproductive success in two subspecies of Juniperus oxycedrus L. Int J Plant Sci. 159: 843-847.

Oszmianski J, Wojdylo A, lamer-Zarawska E, Swiader K (2007) Antioxidant tannins from Rosaceae plant roots. Food Chem. 100: 579-583.

Perez-Bermudez P, Sommer HE (1987) Factors affecting adventitious bud induction in Pinus elliottii (Engelm.) embryos cultured in vitro. Plant Cell Tiss Organ Cult. 11: 25-35.
Pierik RLM (1997) In vitro culture of higher plants. Kluwer Academic Publishers Group, Dordrecht, Boston, Lancaster.

Plaza-Wüthrich S, Blösch R, Tadele Z (2015) Efficiency of in vitro regeneration is dependent on the genotype and size of explants in tef [Eragrostis tef (Zucc.) Trotter]. Adv Crop Sci Tech. 3: 1-7.

Rehman HU (2014) In vitro culture establishment of patharnakh and kainth as effected by explant size and media type. International Journal of Advanced Research in Science, Engineering and Technology. 1: 212-215.

Rossini pinto AC, Rodrigues JD, Leits CI, Barbosa JC (2005) Growth retardants on development and ornamental quality of potted 'liliput' Zinnia elegans JACQ. Sci Agric. 62: 337-345.

Rugini E (1984) In vitro propagation of some olive (Olea europaea L. var. sativa) cultivars with different root-ability, and medium development using analytical data from developing shoots and embryos. Sci Hort. 24: 123-134.

Schenk RV, Hildebrandt AC (1972) Medium and techniques for induction and growth of monocotyledonous and dicotyledonous plant cell cultures. Can J Bot. 50: 199-204.

Shanjani PS (2003) Nitrogen effect on callus induction and plant regeneration of Juniperus excels. Int J Agri Biol. 5: 419-422.

Singleton VL, Orthofer R, Lamuela-Raventós RM (1999) Analysis of total phenols and other oxidation substrates and antioxidants by means of folin-ciocalteu reagent. Method Enzymol. 299: 152-178.

Stoma S, Lucas M, Chopard J, Schaedel M, Traas J, Godin C (2008) Flux-based transport enhancement as a plausible unifying mechanism for auxin transport in meristem development. Available at: http://dx.doi.org/10.1371/journal.pcbi.1000207. Access: March 14th, 2017.

Syouf MQ, Duwayri MA (1995) Jordan: country report to the FAO international technical conference on plant genetic resources. Leipzig. Available at: http://www.fao.org/pgrfa-gpaarchive/jor/jordan.pdf. Access: April 2nd, 2017.

Turkmen N, Sari F, Poyrazoglu ES, Velioglu YS (2006) Effects of prolonged heating on antioxidant activity and colour of honey. Food Chem. 95: 653-657.

Van Berkel K, De Boer RJ, Scheres B, Ten Tusscher K (2013) Polar auxin transport: models and mechanisms. Development. 140: 2253-2268.

Wesche K, Ronnenberg K, Hensen I (2005) Lack of sexual reproduction within mountain steppe populations of the clonal shrub Juniperus sabina L. in semi-arid southern Mongolia. J Arid Environ. 63: 390-405.

Yen GC, Duh PD (1994) Scavenging effect of methanolic extracts of peanut hulls on free-radical and active oxygen species. J Agr Food Chem. 42: 629-632.

Zaidi MA, Khan S, Jahan N, Yousafzai A, Mansoor A (2012) Micropropagation and conservation of three Juniperus species (Cupressaceae). Pak J Bot. 44: 301-304.

Zhishen J, Mengcheng T, Jianming W (1999) The determination of flavonoid contents in mulberry and their scavenging effects on superoxide radicals. Food Chem. 64: 555-559. 